\title{
Interaction between Trichomonas vaginalis and other pathogenic micro-organisms of the human genital
}

\section{tract}

\author{
D A STREET,* C WELlS,† D TAYLOR-ROBINSON,* AND J P ACKERS
}

From the *Sexually Transmitted Diseases Research Group, Division of Communicable Diseases and $\uparrow$ Division of Histopathology, MRC Clinical Research Centre, Harrow, Middlesex and the $\ddagger$ London School of Hygiene and Tropical Medicine, London

SUMMARY Trichomonas vaginalis organisms were mixed with suspensions of Neisseria gonorrhoeae, Mycoplasma hominis or Chlamydia trachomatis to allow ingestion of these microorganisms by the trichomonads. Culture studies indicated that gonococci and mycoplasmas were ingested and that the number of intracellular viable organisms decreased rapidly, most gonococci being killed within six hours and all mycoplasmas within three hours. Electron microscopy revealed phagocytic uptake and destruction of these two micro-organisms within the trichomonads, gonococcal degradation being associated with lysosomal enzyme activity. There was no evidence from cultural or electron microscopy studies that $C$ trachomatis organisms persisted in mixed culture with $T$ vaginalis.

\section{Introduction}

Trichomonas vaginalis, a parasitic protozoan of the human urogenital tract, is actively phagocytic. It has been suggested that it can enhance the pathogenicity of other micro-organisms, for example gonococci, mycoplasmas, and chlamydiae, in the urogenital tract by ingesting and protecting them from the defences of the host and from the inhibitory effects of antibiotics used for treatment, while transporting them to uncolonised parts of the urogenital tract or to new hosts. ${ }^{1}$ In this regard, treatment failures in gonorrhoea have been ascribed to concomitant infection with $T$ vaginalis. ${ }^{2}$ This hypothesis for the protective role of trichomonads is based almost exclusively on the observations, by electron microscopy, of apparently intact gonococci and mycoplasmas within trichomonads in vaginal secretions of women from whom both $T$ vaginalis and Neisseria gonorrhoeae were isolated. . $^{3-5}$ There have also been several reports suggesting an epidemiological association between trichomoniasis and gonorrhoea, ${ }^{67}$ or infection with mycoplasmas. ${ }^{89}$

Address for reprints: $\mathrm{Dr}$ D Taylor-Robinson, Division of Communicable Diseases, Clinical Research Centre, Watford Road, Harrow, Middlesex HAI 3UJ

Accepted for publication 31 May 1983
In view of these observations and their implications, we considered that it would be valuable to establish in vitro whether $N$ gonorrhoeae, Mycoplasma hominis and Chlamydia trachomatis organisms were ingested by $T$ vaginalis and, if so, whether they were killed by the protozoan or remained viable for sufficient time to contribute to their pathogenicity in the ways outlined.

\section{Materials and methods}

SOURCE AND MAINTENANCE OF MICROORGANISMS

$T$ vaginalis strains were isolated from infected symptomatic women by inoculation of vaginal secretion into $5 \mathrm{ml}$ of agar free Diamond's medium ${ }^{10}$ containing 1000 units $/ \mathrm{ml}$ penicillin, $500 \mu \mathrm{g} / \mathrm{ml}$ streptomycin, and $50 \mu \mathrm{g} / \mathrm{ml}$ nystatin. After incubation at $37^{\circ} \mathrm{C}$ for 24 hours, the strains were subcultured in Diamond's medium containing 5 $\mu \mathrm{g} / \mathrm{ml}$ vancomycin hydrochloride and $3 \mu \mathrm{g} / \mathrm{ml}$ colistin sulphomethate sodium (Pharmax, Bexley, Kent, United Kingdom). Passage was repeated at three to four day intervals but no strain was passed more than five times before use.

A suspension of trichomonads for each experiment was prepared by taking $10 \mathrm{ml}$ of a culture which had been incubated at $37^{\circ} \mathrm{C}$ for 72 hours, at which time 
the organisms were in the logarithmic phase of growth and actively motile, and centrifuging it at $1,000 \times g$ for five minutes in a bench centrifuge. The deposit was resuspended in medium appropriate for the micro-organisms with which the trichomonads were to be mixed.

$N$ gonorrhoeae, strain E56818, was isolated from a male patient whose urethral discharge contained typical diplococci as shown by Gram staining. GC agar medium (Difco) supplemented with Isovitalex (BBL, Baltimore, United States) was inoculated and incubated at $37^{\circ} \mathrm{C}$ for 18 hours in an atmosphere of air containing $5 \%$ carbon dioxide. Colonies of both type 1 and type 4 developed and were segregated by selective cloning.

$M$ hominis, strain 12833, was isolated from a female patient. A vaginal swab was inoculated into Stuart's transport medium. This was subcultured and titrated in mycoplasma liquid medium containing arginine, ${ }^{11}$ which was incubated at $37^{\circ} \mathrm{C}$ for 72 hours. A stock culture was produced by inoculating approximately $10^{6}$ colour changing units (ccu) of the mycoplasmas into $20 \mathrm{ml}$ of medium containing arginine which was incubated at $37^{\circ} \mathrm{C}$ for 48 hours.

$C$ trachomatis, strain 48/80H (serotype unknown), was isolated by the McCoy cell technique ${ }^{12}$ from the cervix of a female contact of a man presenting with non-gonococcal urethritis. After two passes in McCoy cells the chlamydiae were suspended in a solution comprising equal parts of a complete tissue culture medium with glucose and antibiotics (CMGA) ${ }^{12}$ and sucrose phosphate solution and were stored at $-70^{\circ} \mathrm{C}$.

\section{MIXING OF MICRO-ORGANISMS \\ $T$ vaginalis and $N$ gonorrhoeae}

Colonies of $N$ gonorrhoeae were scraped from the agar and emulsified in $1.5 \mathrm{ml}$ of tryptone-soya broth containing $10 \%$ calf serum (TSB $+\mathrm{S}$ ), $\mathrm{pH} 7 \cdot 0$, so that there were approximately $10^{8}$ colony forming units $(\mathrm{cfu}) / \mathrm{ml}$. One $\mathrm{ml}$ of the suspension was removed carefully to avoid clumps and added to $3.6 \times 10^{6}$ motile $T$ vaginalis organisms (strain 77961 , fourth passage) contained in $1 \mathrm{ml}$ of TSB $+S$ in a sterile plastic $20 \mathrm{ml}$ bottle (Sterilin). The ratio of gonococci to trichomonads was approximately 100:1. The suspension was mixed gently and incubated at $37^{\circ} \mathrm{C}$ for 30 minutes to allow ingestion of the gonococci. Then $2 \mathrm{ml}$ of a "cocktail" of $4 \%$ guinea pig serum, $60 \%$ normal human serum, and $160 \mu \mathrm{g}$ of spectinomycin in TSB $+\mathrm{S}$ were added and incubation continued for a further 20 minutes. Preliminary experiments had shown that this mixture killed most of the extracellular gonococci within 20 minutes without adversely affecting the intracellular organisms. After 20 minutes the $4 \mathrm{ml}$ suspension of organisms was diluted to $15 \mathrm{ml}$ with TSB $+\mathrm{S}$ and this volume was centrifuged at $1000 \times g$ for three minutes. Two $0.1 \mathrm{ml}$ samples of the supernatant fluid were assayed for viable gonococci (see below). The pellet was washed twice in TSB $+\mathrm{S}$, resuspended in $8 \mathrm{ml}$ of TSB $+\mathrm{S}$, and the suspension incubated at $37^{\circ} \mathrm{C}$ in an atmosphere of air with $5 \%$ carbon dioxide. After 30 minutes and 1, 2, 3, 5, 10, and 21 hoùrs, $1.0 \mathrm{ml}$ samples were removed from the suspension for gonococcal culture, electron microscopy, and estimation of the number of motile trichomonads. A $0.4 \mathrm{ml}$ volume of each sample was sonicated (Dawe $R$ soniprobe, Dawe Instruments Ltd) for five seconds at the lowest setting, after which whole trichomonad cells could not be detected; the results of preliminary experiments had indicated that gonococci were unaffected by this procedure. To estimate the number of viable gonococci, two $0.1 \mathrm{ml}$ of aliquots of the sonicate were diluted serially in tenfold steps in warm Eagle's minimal essential medium. A $0 \cdot 1 \mathrm{ml}$ volume of each dilution was placed on GC agar medium which was incubated as described above. Another $0.1 \mathrm{ml}$ of the sample was used to estimate the number of motile trichomonads, using a counting chamber. The remaining $0.5 \mathrm{ml}$ of the unsonicated sample was added to an equal volume of $6 \%$ glutaraldehyde fixative in 0.1 mol/l cacodylate buffer and processed for electron microscopy as described below.

As controls, suspensions of each micro-organism alone were treated in the same way. Samples were withdrawn initially and $2,6,11$, and 22 hours after incubation at $37^{\circ} \mathrm{C}$ for electron microscopy of $T$ vaginalis and for determination of the number of viable gonococci.

The mixed suspension was Gram stained at the beginning and end of the experiment, as were smears of some of the colonies which developed on the GC agar medium. In addition, a sample of the mixed culture was examined by conventional bacteriological techniques at the end of the experiment to check for bacterial contamination.

$T$ vaginalis and $M$ hominis.

A $1.0 \mathrm{ml}$ volume of a suspension of approximately $10^{9} \mathrm{M}$ hominis organisms was added to $9.0 \mathrm{ml}$ of warm arginine medium containing $10^{7} T$ vaginalis organisms (strain 27, fourth passage). The ratio of mycoplasmas to trichomanads was, therefore, about 100:1. The mixed suspension was incubated at $37^{\circ} \mathrm{C}$ for one hour to allow ingestion of the mycoplasmas, after which it was centrifuged at $1000 \times g$ for five minutes. The pellet was resuspended in medium containing arginine and washed twice more to remove as many extracellular mycoplasmas as possible. Gentamicin (final concentration of 500 $\mu \mathrm{g} / \mathrm{ml}$ ) and streptomycin (final concentration of 5000 
$\mu \mathrm{g} / \mathrm{ml}$ ) were then added to inhibit the multiplication of any remaining non-ingested mycoplasmas. The results of preliminary experiments had shown that these antibiotics at these concentrations did not kill $T$ vaginalis organisms or enter them sufficiently to affect intracellular mycoplasmas. Samples of $1.0 \mathrm{ml}$ were removed immediately after mixing the two micro-organisms and after 30 minutes and 1, 2, 3, 4, 6,11 , and 22 hours. Half of each sample was added immediately to an equal volume of $6 \%$ glutaraldehyde fixative and processed for electron microscopy. The organisms in the remaining $0.5 \mathrm{ml}$ of each sample were washed to remove most of the antibiotics by centrifuging at $1000 \times g$ for five minutes and resuspending in $0.5 \mathrm{ml}$ of medium containing arginine. Two aliquots of $0.25 \mathrm{ml}$ were then placed in $2 \mathrm{ml}$ capacity sterile plastic liquid nitrogen vials (NUNC) and sonicated for five seconds to disrupt the trichomonads. Then serial tenfold dilutions were made in warm arginine medium to determine the number of viable mycoplasmas. At each sampling the number of motile trichomonads in the mixed culture was estimated.

A suspension of mycoplasmas alone, acting as a control, was incubated at $37^{\circ} \mathrm{C}$ alongside the mixed culture and samples were withdrawn for estimation of the number of viable organisms after $2,6,11$, and 22 hours. In addition, a sample of the trichomonads was taken before mixing the cultures and was sonicated and titrated for the presence of $M$ hominis.

\section{$T$ vaginalis and $C$ trachomatis}

$T$ vaginalis organisms of strain 68 (fifth passage) and strain 27 (fourth passage) were suspended separately in $11 \mathrm{ml}$ of CMGA medium so that trichomonads numbered about $5 \times 10^{5} / \mathrm{ml}$. A $1.0 \mathrm{ml}$ volume of CMGA containing approximately $5 \times 10^{8}$ inclusion forming units of $C$ trachomatis was added so that the final ratio of chlamydiae to trichomonads was approximately 100:1. The suspension was incubated at $37^{\circ} \mathrm{C}$ with occasional gentle agitation. Samples were removed immediately and at $24,48,72,96$, and 120 hours, at which times $1.0 \mathrm{ml}$ of the culture was added to $1.0 \mathrm{ml}$ of $6 \%$ glutaraldehyde fixative and processed for electron microscopy. Two further 0.5 ml samples of culture were filtered through a sterile $0.22 \mu \mathrm{m}$ filter (Millipore) to retain trichomonads but allow the passage of chlamydiae and $0.25 \mathrm{ml}$ of the filtrate was added to $0.25 \mathrm{ml}$ of sucrose phosphate buffer (fourfold concentration (4SP)) and stored in liquid nitrogen. The filter was carefully washed by filtering $20 \mathrm{ml}$ of sterile warm CMGA through it, and the trichomonads remaining on the filter were suspended in $0.5 \mathrm{ml}$ of sucrose phosphate buffer (twofold concentration). This suspension was sonicated for five seconds and then stored in liquid nitrogen until assayed for chlamydiae. At each sampling, the number and motility of the trichomonads in the mixed culture were estimated.

As controls, samples of each micro-organism were suspended alone in CMGA. The samples of $T$ vaginalis alone were examined at the beginning and at the end of the experiment for chlamydiae. Duplicate $0.2 \mathrm{ml}$ samples were removed from the chlamydial control at the same times as from the mixed culture. These were added to $0.2 \mathrm{ml}$ of $4 \mathrm{SP}$ and stored in liquid nitrogen before testing. Chlamydiae were detected by using $\mathrm{McCoy}$ cells treated with cycloheximide which were Giemsa stained and examined by dark ground microscopy. ${ }^{12}$

TABLE I Survival of $N$ gonorrhoeae after mixing with $T$ vaginalis

\begin{tabular}{|c|c|c|c|c|c|c|c|}
\hline \multirow[b]{2}{*}{$\begin{array}{l}\text { Specimens } \\
\text { tested }\end{array}$} & & \multicolumn{2}{|c|}{$\begin{array}{l}\text { No of gonococci (cfu/ml) of } \\
\text { colony type I recovered from: }\end{array}$} & \multirow[b]{2}{*}{$\begin{array}{l}\text { No of } \\
\text { motile } \\
\text { trichomonads }\end{array}$} & \multicolumn{2}{|c|}{$\begin{array}{l}\text { No of gonococci }(c f u / m l) \text { of } \\
\text { colony type } 4 \text { recovered from: }\end{array}$} & \multirow[b]{2}{*}{$\begin{array}{l}\text { No of } \\
\text { motile } \\
\text { trichomonads }\end{array}$} \\
\hline & & $\begin{array}{l}\text { Gonococcus } \\
\text { \& trichomonad } \\
\text { mixture }\end{array}$ & $\begin{array}{l}\text { Gonococcus } \\
\text { suspension } \\
\text { only }\end{array}$ & & $\begin{array}{l}\text { Gonococcus } \\
\text { \& trichomonad } \\
\text { mixture }\end{array}$ & $\begin{array}{l}\text { Gonococcus } \\
\text { suspension } \\
\text { only }\end{array}$ & \\
\hline $\begin{array}{l}\text { Initial } \\
\text { preparation }\end{array}$ & & $96 \times 10^{6}$ & $120 \times 10^{6}$ & $1.65 \times 10^{6}$ & $260 \times 10^{6}$ & $570 \times 10^{6}$ & $2.4 \times 10^{6}$ \\
\hline $\begin{array}{l}\text { Supernatant } \\
\text { fluid after } \\
\text { antibiotics }\end{array}$ & & $<20$ & NA & NA & $<20$ & NA & NA \\
\hline $\begin{array}{l}\text { Washed and } \\
\text { sonicated } \\
\text { trichomonads* } \\
\text { at following } \\
\text { times after } \\
\text { incubation }\end{array}$ & $\begin{array}{l}0 \\
30 \mathrm{~min} \\
1 \mathrm{hr} \\
2 \mathrm{hr} \\
3 \mathrm{hr} \\
4 \mathrm{hr} \\
6 \mathrm{hr} \\
11 \mathrm{hr} \\
22 \mathrm{hr}\end{array}$ & $\begin{array}{r}3.5 \times 10^{6} \\
2.6 \times 10^{6} \\
3.7 \times 10^{6} \\
2.4 \times 10^{6} \\
0.21 \times 10^{6} \\
0.088 \times 10^{6} \\
6800 \\
86 \\
<20\end{array}$ & $\begin{array}{r}170 \times 10^{6} \\
198 \times 10^{6} \\
101 \times 10^{6} \\
18 \times 10^{6} \\
0.032 \times 10^{6}\end{array}$ & $\begin{array}{l}1.45 \times 10^{6} \\
1.9 \times 10^{6} \\
2.25 \times 10^{6}\end{array}$ & $\begin{array}{c}0.89 \times 10^{6} \\
0.84 \times 10^{6} \\
0.78 \times 10^{6} \\
0.26 \times 10^{6} \\
17000 \\
10600 \\
900 \\
<20 \\
<20\end{array}$ & $\begin{array}{l}490 \times 10^{6} \\
540 \times 10^{6}\end{array}$ & $\begin{array}{l}2 \cdot 1 \times 10^{6} \\
2 \cdot 4 \times 10^{6} \\
4 \cdot 1 \times 10^{6}\end{array}$ \\
\hline
\end{tabular}

cfu $=$ colony forming units; $\mathrm{NA}=$ not applicable; * = applicable only to the mixture. 


\section{ELECTRON MICROSCOPY}

All samples were prepared for electron microscopy as follows. After fixation for two hours at room temperature in glutaraldehyde at a final concentration of $3 \%$, the organisms were centrifuged at $1000 \times g$ for five minutes and the deposit washed again with $0.1 \mathrm{~mol} / 1$ cacodylate buffer, after which it was postfixed by resuspension in $1 \%$ osmium tetroxide for one hour at $4^{\circ} \mathrm{C}$. Then the organisms were centrifuged as before, the deposit washed with distilled water, and the organisms recentrifuged in $2 \%$ low-gel-temperature agar to facilitate handling. They were dehydrated in graded acetone and embedded in Spurr's resin. Specimens were stained with uranyl acetate and lead citrate and viewed in a Phillips EM300 electron microscope.

The acid phosphatase cytochemistry was carried out according to the method of Holt and Hicks using sodium $\beta$-glycerophosphate as substrate. ${ }^{13}$ The specimens were embedded as before but stained only with uranyl acetate to enhance the lead precipitate.

\section{Results}

\section{N GONORRHOEAE}

Culture study

Table I shows the results of one experiment in which colony types 1 and 4 of $N$ gonorrhoeae were mixed

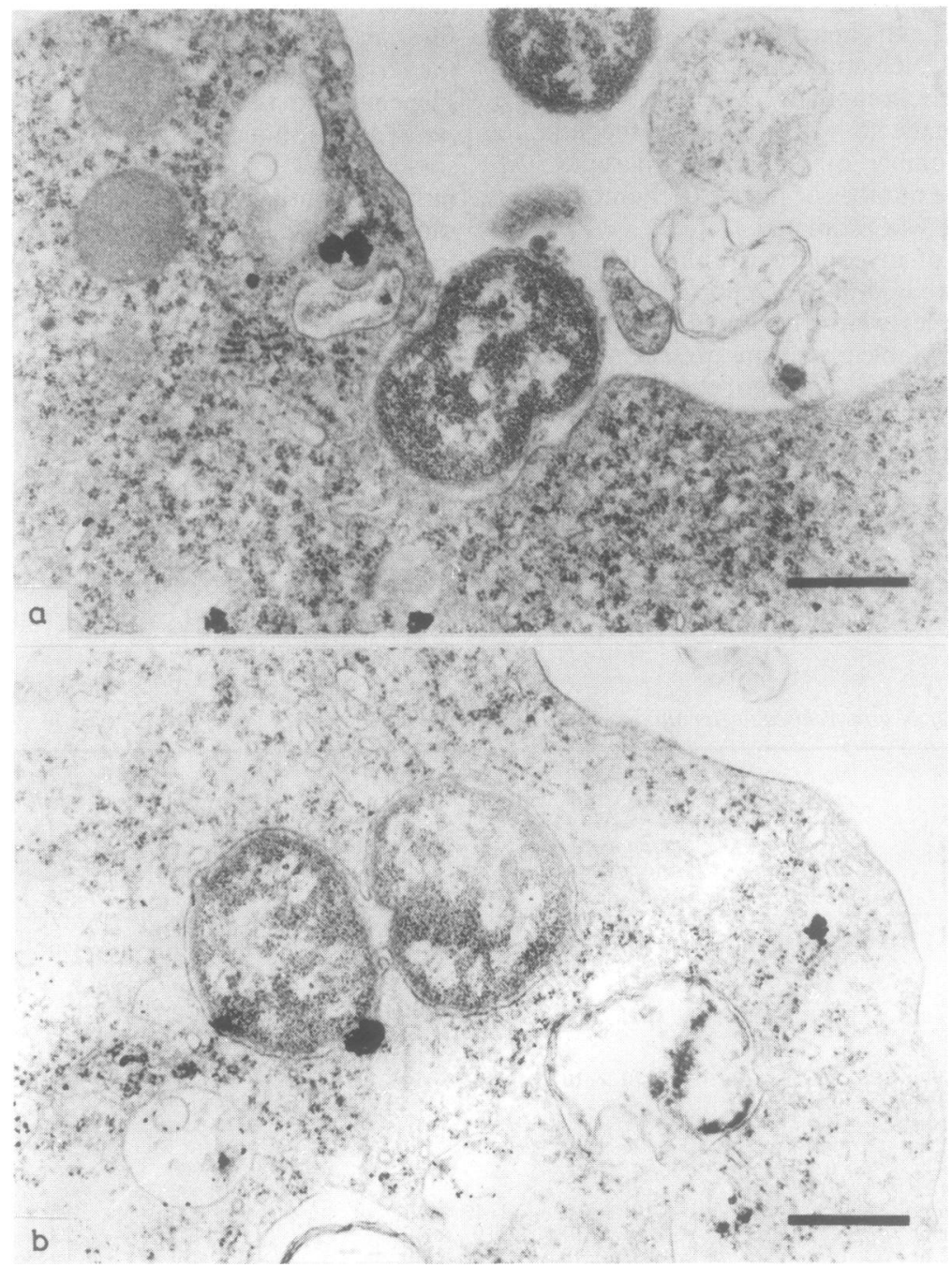

FIG 1 Electron micrograph of gonococci a) entering and b) in a $T$ vaginalis cell within 30 minutes of mixing (bars represent $0.5 \mu \mathrm{m}$ ). 
with $T$ vaginalis. The results of two other experiments were similar. Gonococci were not detected in the supernatant fluids of the mixed cultures after antibiotic treatment of serum, or in the deposit of trichomonads after centrifugation, but they were found after sonication of the trichomonads, indicating that some had become intracellular. Within the cells, the gonococci lost their viability more rapidly than gonococci in the control suspension without $T$ vaginalis. After an initial lag phase of about one hour, half the bacteria were killed in approximately one hour and more than $99 \%$ in six hours. There was no appreciable difference between the behaviour of colony type 1 and type 4 gonococci.

\section{Electron microscopy observations}

Electron microscopy examination of sections through the trichomonads showed that gonococci were entering or had entered them during the 30 minute mixing period, and appeared structurally intact (fig 1a, b). Thereafter there was evidence of rapid destruction of the bacteria; by three hours most of their internal structure had been lost and after six hours they were scarcely recognisable as bacteria and were found at sites of intense lysosomal enzyme (acid

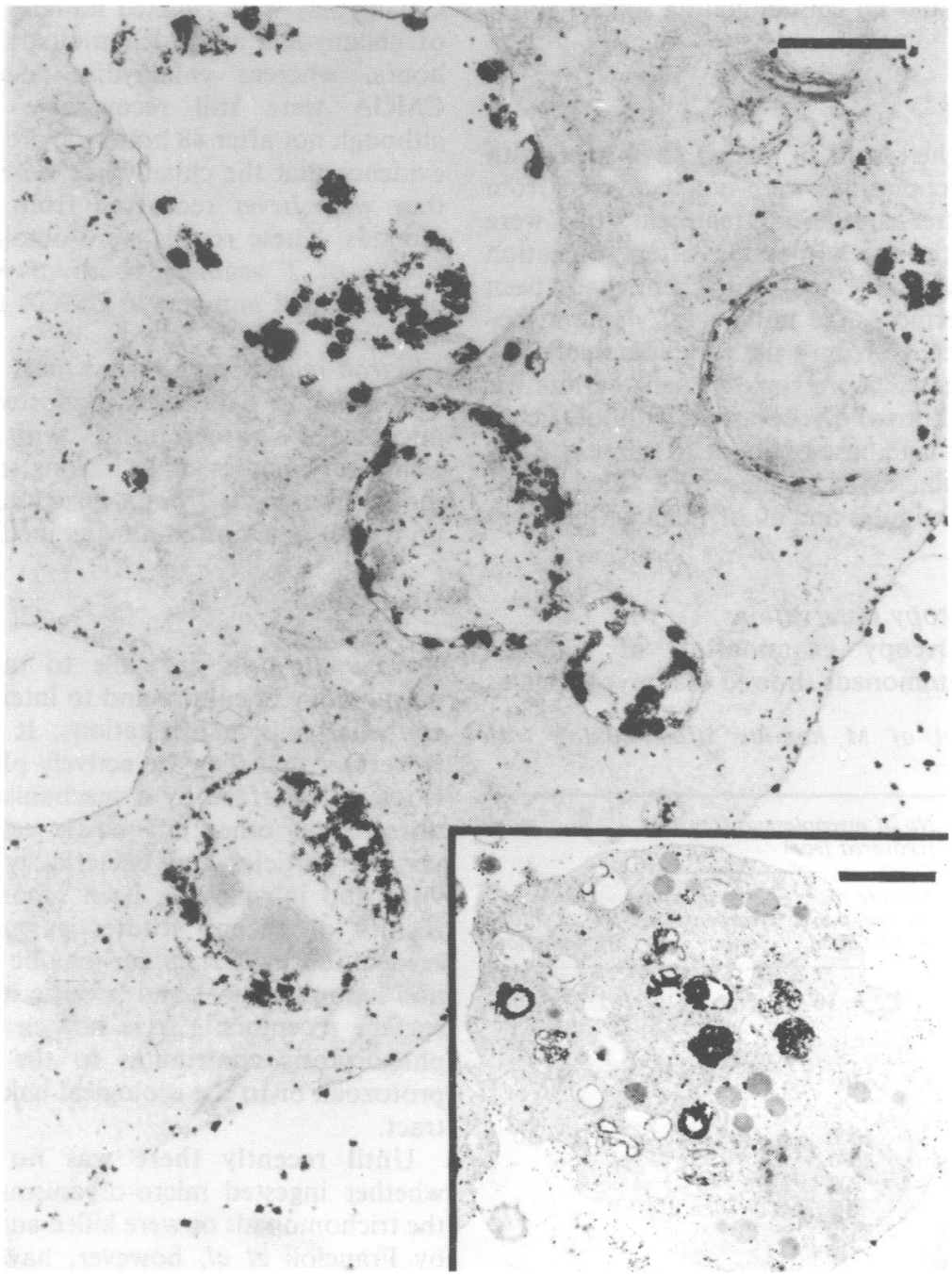

FIG 2 Electron micrograph of gonococci in a $T$ vaginalis cell eight hours after mixing. Bacterial destruction and heavy deposits of lead indicate intense acid phosphatase activity (bar represents $0.5 \mu \mathrm{m}$ ). Inset: further illustration of the same, also at eight hours (bar represents $2 \cdot 0 \mu \mathrm{m}$ ). 
phosphatase) activity. The latter was indicated by lead deposits which could be seen initially as small discrete granules in the trichomonads. The activity of acid phosphatase, however, judged by the amount of lead deposited, increased as the number of ingested bacteria increased. Eight hours after mixing (fig 2) deposits of lead were seen on the luminal aspect of the phagosome membrane and on the vesicles' contents, and after 12 hours the phagosomes contained debris only, intact gonococci not being seen.

Gram staining the suspensions of gonococci and trichomonads failed to reveal any bacteria other than $N$ gonorrhoeae, and no contaminating species could be cultured.

\section{HOMINIS \\ Culture study}

Table II shows the results of mixing $M$ hominis with $T$ vaginalis. Mycoplasmas were not recovered from the mixtures after antibiotic treatment, but were isolated from the trichomonads after sonication which indicated that some of them had been ingested. Furthermore, the number of viable mycoplasmas recovered from the trichomonads by sonication decreased more rapidly than the number in the control culture of mycoplasmas without trichomonads. After a lag phase of about 30 minutes, $90 \%$ of the intracellular mycoplasmas were killed in the following 30-90 minutes and all of them within three hours.

\section{Electron microscopy observations}

Electron microscopy examination of sections through the trichomonads showed that mycoplasmas

TABLE II Survival of $M$ hominis after mixing with $T$ vaginalis

\begin{tabular}{|c|c|c|c|c|}
\hline \multirow[b]{2}{*}{$\begin{array}{l}\text { Specimens } \\
\text { tested }\end{array}$} & & \multicolumn{2}{|c|}{$\begin{array}{l}\text { No of mycoplasmas }(\mathrm{ccu} / \mathrm{ml}) \\
\text { recovered from }\end{array}$} & \multirow[b]{2}{*}{$\begin{array}{l}\text { No of motile } \\
\text { trichomonads }\end{array}$} \\
\hline & & $\begin{array}{l}\text { Mixture of } \\
\text { mycoplasma \& } \\
\text { trichomonad }\end{array}$ & $\begin{array}{l}\text { Mycoplasma } \\
\text { suspensison } \\
\text { only }\end{array}$ & \\
\hline $\begin{array}{l}\text { Initial } \\
\text { preparation }\end{array}$ & & $20 \times 10^{6}$ & $20 \times 10^{6}$ & $1.5 \times 10^{6}$ \\
\hline $\begin{array}{l}\text { Supernatant } \\
\text { fluid after } \\
\text { antibiotics }\end{array}$ & & $<10$ & NA & NA \\
\hline $\begin{array}{l}\text { Washed and } \\
\text { sonicated } \\
\text { trichomonads* } \\
\text { at following } \\
\text { times after } \\
\text { incubation }\end{array}$ & $\begin{array}{c}0 \\
30 \mathrm{~min} \\
1 \mathrm{hr} \\
2 \mathrm{hr} \\
3 \mathrm{hr} \\
4 \mathrm{hr} \\
6 \mathrm{hr} \\
10 \mathrm{hr} \\
20 \mathrm{hr}\end{array}$ & $\begin{array}{r}2000 \\
2000 \\
200 \\
200 \\
<10 \\
<10 \\
<10 \\
<10 \\
<10\end{array}$ & $\begin{array}{r}20 \times 10^{6} \\
20 \times 10^{6} \\
20 \times 10^{6} \\
0.2 \times 10^{6}\end{array}$ & $\begin{array}{r}1.4 \times 10^{6} \\
1.5 \times 10^{6} \\
1.95 \times 10^{6}\end{array}$ \\
\hline
\end{tabular}

ccu $=$ colour changing units; NA = not applicable; * = applicable only to the mixture. had entered them during the 30 minute mixing period, a considerable number of organisms being present in vacuoles. One hour after mixing the number of intact mycoplasmas in the vacuoles began to decrease, and both undamaged and damaged organisms could be seen (fig 3a). After three hours most of the organisms had degenerated and were barely discernible as mycoplasmas (fig $3 \mathrm{~b}$ ). No intact mycoplasmas were seen by six hours, the vacuoles containing degenerate material only.

\section{TRACHOMATIS}

\section{Culture study}

Chlamydiae were isolated initially from the mixture of chlamydiae and trichomonads but not after 24 hours, whereas chlamydiae incubated alone in CMGA were still recoverable after 24 hours, although not after $\mathbf{4 8}$ hours. There was, however, no evidence that the chlamydiae were ingested because they were never recovered from disrupted trichomonads. These results were obtained with the two strains of $T$ vaginalis, both of which survived in undiminished numbers in CMGA for 120 hours.

\section{Electron microscopy observations}

The isolation data were supported by the electron microscopy observations, with no chlamydial elementary bodies or inclusions seen in sections of the trichomonads from a mixed culture at any time up to 120 hours after starting incubation.

\section{Discussion}

$T$ vaginalis cells are able to take on amoeboid morphology in culture and to interdigitate with host epithelial cells in infestations. It is not surprising, therefore, that they are actively phagocytic over the whole cell surface by a mechanism similar to that observed in other phagocytic cells. ${ }^{14}$ Ingestion of various particles and bacteria by trichomonads in vitro and in vivo has been reported, ${ }^{4-6} 14$ and the results of recent studies suggest that particle recognition by $T$ vaginalis may be mediated by both non-immunological and specific immunological cell surface receptors. ${ }^{15}$ It is not clear, however, how phagocytosis contributes to the nutrition of the protozoan or to the ecological balance of the genital tract.

Until recently there was no information on whether ingested micro-organisms persisted within the trichomonads or were killed and digested. Studies by Francioli et al, however, have shown that the numbers of viable gonococci decrease when incubated with $T$ vaginalis, ${ }^{14}$ and Szreter claimed that six hours after mixing trichomonads with gonococci, $5-20 \%$ of the original bacteria were still able to grow, 
implicating trichomonads as "a potential source of bacterial invasion". ${ }^{16}$

Our in vitro studies confirm and extend the observations of Francioli et al. ${ }^{14}$ The results of culture and electron microscopy indicate that gonococci and $M$ hominis organisms are ingested by $T$ vaginalis and are rapidly inactivated and digested, as shown previously for some other bacteria. ${ }^{17}{ }^{18} \mathrm{We}$ have shown that the lysosomal enzyme, acid phosphatase, accumulates in the phagosomes around the ingested gonococci. This enzyme is specific for internal membranes, indicating that the gonococci were within vacuoles and not just within invaginations of the trichomonad surface. More enzyme activity was found in the Golgi of cells actively engaged in phagocytosis than in non-phago- cytic control cultures, which is in keeping with Nielsen's observation that primary lysosomes were more numerous in trichomonads which had engulfed bacteria than in cells showing no phagocytosis. ${ }^{18}$ It seems, therefore, that the ingestion process stimulates the production of enzymes, and it is tempting to postulate that they are instrumental in the destruction of gonococci. An obvious explanation for the finding by some workers of intact gonococci within phagosomes during electron microscopy studies of clinical material from patients with a mixed infection is that they were newly ingested bacteria.

Demonstration by electron microscopy of the ingestion and destruction of $M$ hominis proved more difficult. Several workers have claimed to have seen

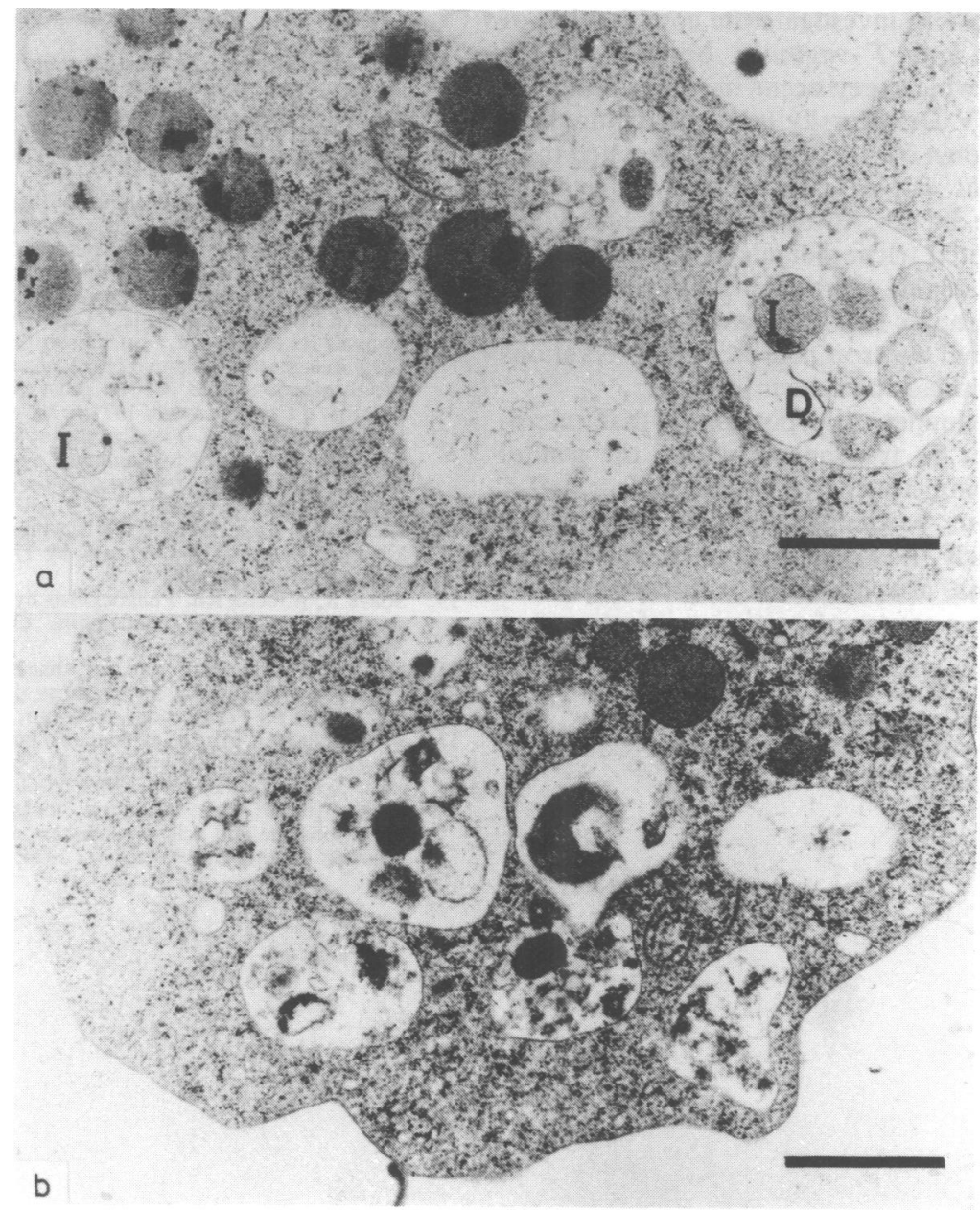

FIG 3 Electron micrographs of $M$ hominis organisms in $T$ vaginalis cells a) intact (I) and damaged (D) organisms in vacuoles one hour after mixing (Bar represents $I \cdot 0 \mu \mathrm{m})$ b) organisms three hours after mixing when almost all have degenerated (bar represents $1.0 \mu \mathrm{m}$ ). 
mycoplasmas within $T$ vaginalis. ${ }^{34}$ Mycoplasmas, however, lack a cell wall, vary in size and shape, and have no characteristic internal structure so that within cells they may be difficult to identify, even by high power electron microscopy. We attempted to label $M$ hominis with ${ }^{3} \mathrm{H}$-thymidine and ${ }^{14} \mathrm{C}$-amino acids but the activity incorporated was insufficient for successful autoradiography. Nevertheless, despite the difficulties we are convinced that the structures we saw by conventional electron microscopy within the vacuoles were mycoplasmas. These observations support the results of the culture studies which, in themselves, leave no doubt that there was rapid killing of the mycoplasmas.

The number of micro-organisms that could be considered in combination with $T$ vaginalis is almost endless. We chose to investigate the combination of $C$ trachomatis and $T$ vaginalis because of the frequency with which they occur in the genital tract and because V V Delektorsky (personal communication) from his own observations had suggested to us that $T$ vaginalis could enhance the survival of chlamydiae. We did not, however, isolate chlamydiae from our disrupted trichomonads at any time up to 120 hours after mixing. Although we did not undertake autoradiographic studies, there was no evidence from conventional electron microscopy observations that the trichomonads became infected.

We cannot eliminate the possibility that microorganisms might be transported within the genital tract by adhering to the external surface of $T$ vaginalis without becoming ingested. Our results show quite clearly, however, that once ingested the micro-organisms are degraded rapidly and are unlikely to form a source of persisting infection.

We thank Mr R T Evans and Dr A P Johnson for help with the chlamydial and gonococcal aspects of the work. This study was supported by a Medical Research Council research studentship grant to DAS.

\section{References}

1. Ovčinnikov NM, Delektorskij VV, Turanova EN, Yashkova GN. Further studies of Trichomonas vaginalis with transmission and scanning electron microscopy. Br J Vener Dis 1975;51:357-75

2. Ovčinnikov NM, Delektorsky VV, Turanova EN, Yashkova GN. Role of Trichomonas vaginalis in maintaining microbial infection. Akush Ginekol 1979; 7:12-14 (Russian with English summary).

3. Nielsen MH, Nielsen R. Electron microscopy of Trichomonas vaginalis Donné: interaction with vaginal epithelium in human vaginal trichomoniasis. Acta Pathol Microbial Scand 1975;83:305-20.

4. Garcia-Tamayo J, Nunez-Montiel JT, de Garcia HP. An electron microscopic investigation on the pathogenesis of human vaginal trichomoniasis. Acta Cytol 1978;22:447-55.

5. Ovčhinnikov NM, Delektorskij VV. Phagocytosis in the urethral discharge from patients with gonorrhoea. In: Skinner FA, Walker PD, Smith H, eds. Gonorrhoea. Epidemiology and pathogenesis. London: Academic Press, 1977; 157-83.

6. Tsao W. Trichomoniasis and gonorrhoea. $\mathrm{Br}$ Med 1969; 1:642-3.

7. Catterall RD. Diagnosis of vaginal discharge. $\mathrm{Br} J$ Vener Dis 1970; 46: 122-4.

8. Salaman MH. and collaborators. The isolation of organisms of the pleuropneumonia group from the genital tract of men and women. Journal of Pathology and Bacteriology 1946;58:31-5.

9. Spence MR. Correlation between Trichomonas vaginalis and other sexually transmitted agents. Wiad Parazytol 1983;29 (in press).

10. Diamond LS. The establishment of various trichomonads of animals and man in axenic culture. $J$ Parasitol 1957; 43:488-90.

11. Taylor-Robinson D, Martin-Bourgon C, Watanabe T, Addey JP. Isolation of T-mycoplasmas from dogs and squirrel monkeys. Biological and serological comparison with those isolated from men and cattle. J Gen Microbiol 1971; 68:97-107.

12. Thomas BJ, Evans RT, Hutchinson GR, Taylor Robinson D. Early detection of chlamydial inclusions combining the use of cycloheximide-treated McCoy cells and immunofluorescence staining. J Clin Microbiol 1977;6:285-92.

13. Holt SJ, Hicks RM. Localization of acid phosphatase in rat liver cells as revealed by combined cytochemical staining and electron microscopy. Journal of Biophysical and Biochemical Cytology 1961;11:47-66.

14. Francioli $\mathbf{P}$, Shio $\mathbf{H}$, Roberts RB, Muller M. Phagocytosis and killing of Neisseria gonorrhoeae by Trichomonas vaginalis. Infect Dis 1982;147:87-94.

15. Soave R, Roberts RB. Phagocytosis by Trichomonas vaginalis compared to human neutrophils. Clinical Research 1982; 30:379a.

16. Szreter $H$. Survival rate of bacteria phagocytosed by Trichomonas vaginalis. Proceedings of the 5th International Conference on Parasitology. Toronto, Canada: 1982: p 632.

17. Brugerolle MG. Mise en evidence du processus d'endocytose des structures lysomatique chez Trichomonas vaginalis. $C R$ Acad Sci [D] (Paris) 1971; 272:2558-60.

18. Nielsen MH. Fine structural localization of nucleoside triphosphatase and acid phosphatase activity in Trichomonas vaginalis Donné. Cell Tissue Res 1974; 151:269-80. 